\title{
A critical investigation of Romans 4:3: Its determinative value for justice and righteousness ${ }^{1}$
}

\author{
Nagel, Peter \\ University of the Free State \\ admin@peternagel.co.za
}

\begin{abstract}
The theological significance of Romans 4 is undisputed and within it the explicit citation in Romans 4:3 is pivotal. It has informed theological thought, stimulated debates, and shaped faith communities for millennia. But does the concept of 'justification by faith' or 'righteousness through faith', as portrayed in Romans 4:3, hold enough essential universal elements for it to inform faith communities in particular and society in general? How did Paul arrive at the idea that through faith one can be declared righteous? Is there any hint in Romans 4:3 to a conceptual relationship between justice and righteousness? The aim of this paper is to critically investigate Romans 4:3 within its literary conceptual context to determine if it has anything significant to offer for societal concepts of justice and righteousness. Such a critical enquiry must include considering Paul's concept of justice and righteousness in comparison to a more modern concept of these terms. This investigation will also demand a critical reflection on Genesis 15:1-21 and Paul's interpretation of the text. One also ought to deal with this matter within the literary context of Romans 3:21-4:25.
\end{abstract}

\section{Keywords}

Romans, justice, righteousness

1 This article is a reworking of a paper delivered at a multi-disciplinary conference on rethinking justice and righteousness in society, held at the University of the Free State in August 2015. The idea to reflect on how texts dealt with the concept of justification by a deity is nothing new. Jozé Krašovec (2014:416-433) wrote an article on the justification of God in His Word in Psalm 51:6 and Romans 3:4, through which he aimed to reflect on the meaning of the passage within the broader context of the bible. 


\section{Introduction}

What makes Romans 4:3 such an intriguingly significant verse is the fact that it is foundational for the concept of 'righteousness through faith' or 'justification by faith' developed in Romans 3:21-4:25. ${ }^{2}$ The explicit citation taken from Genesis 15:6, as reflected in Romans 4:3, also contributes to the significance of the passage and the concept of 'justification by faith' while the interrogative pronoun Tí together with the conjunction oṽ v, formulated as a rhetorical question, sanction Romans 4's dependence on chapters 1-3. ${ }^{3}$ Together they form a noteworthy theological framework dealing with 'sin', 'guilt', 'judgment' and the concept of 'justification by faith'. This concept has become a terminus technicus which poses a threat to its theological and societal value. The threat is caused by the uncritical acceptance of the concept. The concept has become static and its relevance questionable. The aim here is to contribute to the liberation of the concept from its theological stagnate position by means of a critical investigation into Romans 4:3 and the explicit citation (Genesis 15:6) it reflects. Critical questions will be asked such as: "How did Paul understand and interpret Genesis 15:6 in the context of Genesis 15?", 'How did Paul reinterpret Genesis 15:6?”, “To what extent did the explicit citation, taken from Genesis 15:6, influence Paul's understanding of the concept of "righteousness through faith"? The objective here is to give possible answers to these question and by doing so contribute to the dynamic character of the concept of 'righteousness through faith'. As with any study a workable definition of the terms in question is required.

2 Käsemann $(1980: 89,91)$ comments that the scriptural proof of Paul's thesis (Rom 3:2131) 'justification by faith' corresponds to God's direction of salvation history and his will (Rom 4:1-25). He goes further by stating that 'justification by faith' is the center of Romans, of Paul's theology, and indeed of the Bible. According to Hahn (2011:251), Romans 3:21-26 is central to Paul's argumentation and there is no doubt that Romans 3:21-23 is indeed Pauline argumentation, while Romans 3:24 is uncertain and Romans 3:25-26 pre-Pauline (Credo-Aussage).

3 Oeming (1983:182) states that Genesis 15:6 for Paul is an Old Testament locus classicus for the justification through faith alone.

4 Traditional and well established commentaries (Lohse, 2003:146, Schlier 1987:121) and monographs (Dunn, 1998:367-379, Schnelle, 2007:348-355; Hahn, 2011:256-257) dealing with Pauline literature and thought support the contribution made by Romans 4 in relation to the concept of 'righteousness through faith' 


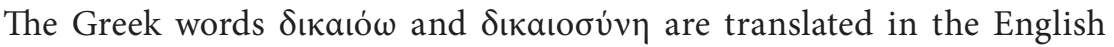
language respectively with the terms 'justified' and 'righteous'. The former emphasises the action while the latter highlights a state of being. Both these terms demand an agent that justifies and declares righteous as well as an agent that is being declared just and deemed righteous. ${ }^{5}$ The term $\delta$ เкaıøv'v $\eta$ also

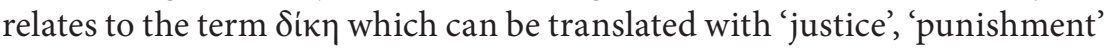

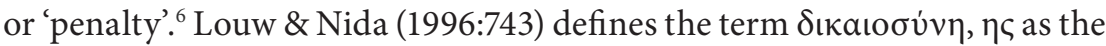
act of 'doing what God requires', 'doing what is right in relation to God.'7 The verb $\delta$ เкaió $\omega$ is defined as 'to justify', 'to deem right'; 'to cause to be in a right relationship with'. ${ }^{8}$ The Hebrew root of these terms are represented by הקדצ which is defined as 'righteousness', 'justice', 'godliness' etc. ${ }^{9}$ and טפשמ which is defined as 'to execute justice and righteousness', 'administer justice'; 'used in the act of judging'; 'that which is lawful'. ${ }^{10}$ The Greek term $\kappa \rho i v \omega$ is used as a Greek equivalent for טפש (to judge), while кpioıs is a reproduction of טפשמ (divine judgment). ${ }^{11}$ Both the Hebrew, and its Greek counterpart (Septuagint / Old Greek), draw a distinction between the act of judgment and the state caused by such a judgement. The English frame of reference, in turn, draws a distinction when dealing with the concept of justice. On the one hand justice is perceived, used, and informed by

5 Holst (1997:319) highlights the idea of subjective faith and objective content. Köckert (2012:415) contributes to this idea when he states the exchange of subject in Genesis 15:6, God justifies and Abram believes, distinguishes Lutheran understanding of justification by faith.

6 (Liddell, 1996:202; Schnelle, 2007:237). Lexicons on the Septuagint suggest meanings such as 'virtue of righteousness' and 'justice' (Lust, Eynikel \& Hauspie, A Greek-

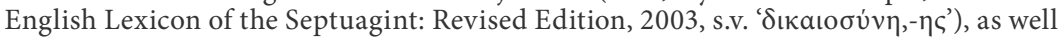
as 'conformity to the dictates of the religion of Israel', 'uprightness', 'proper conduct', 'fairness', and 'rightful entitlement' (Muraoka, 2009:169-170).

7 Moo (1996:87) mentions that Ziesler contends that $\delta$ ıкaı $\omega$ for Paul is always forensic,

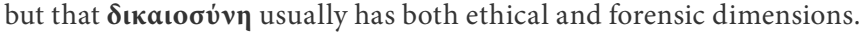

8 Lust, Eynikel \& Hauspie (A Greek-English Lexicon of the Septuagint: Revised Edition,

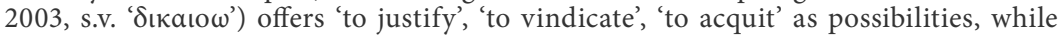
Muraoka (2009:170) propose 'to declare just and righteous', 'to consider in court and pronounce judgment'.

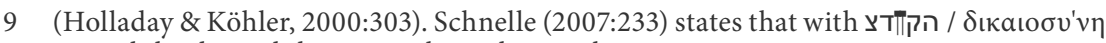
central theological themes are brought together.

10 (Brown, Driver \& Briggs, 1977:842); also see Gesenius \& Tregelles (2003:519) and Hahn (2011:247-248).

11 The term кpírৎ occurs eight times in the New Testament (Jn 3:19; 5:30; 8:16; 12:31; Acts 8:33; Heb 9:27; Js 2:13 and Rev 18:10), while $\kappa \rho i v \omega$ is used more frequently. 
philosophy, theology and religion in societal structures, while on the other hand it describes procedures and applications instructed by law. One can be declared 'guilty' or 'not guilty' in a court of law, based on the rule of law. Paul interpreted being reckoned 'righteous' by the Hebrew deity as only possible through faith. This claim can be corroborated by the fact that he decided on Genesis 15:6 as an explicit citation and proof text as well as the extrapolation from Romans 3:21 onwards (see Rom 3:27, 28, 30; 4:3, 5, 9, $11,22 ; 5: 1)$. It is furthermore clear that one is declared (passive) 'righteous', but this is based on a subjective act of faith. ${ }^{12}$ The Hebrew deity is the agent responsible for the act of declaring someone righteous, but requires an agent that is responsible for the act of believing. Being truthful or factual is not necessarily a requirement, but 'true' intent to believe that something might be true seems to be essential. Paul's aim to include both Jew and 'nonJew' supported the introduction of the concept of 'righteousness' as well as his ideas relating to 'sin', 'wickedness', and 'ungodliness'. ${ }^{13}$ A modern day case of 'sin', 'guilt', 'judgement', 'justice' and 'righteousness' is the recent publically exposed case of South African Olympian Oscar Pistorius, in which Judge Thokozile Masipa had to hand down judgement; a judgment that consisted of 'matters of fact' and 'matters of law', while displaying the element of 'mercy' when the sentence was handed down. Morally speaking, Oscar Pistorius was guilty of murder; legally speaking he was found guilty of culpable homicide, and when sentenced, he was even shown mercy by Judge Masipa. In March of this year, the ruling of culpable homicide was overturned and Oscar Pistorius was found guilty of murder, resulting in the moral and legal perspectives to coincide. During such legal procedures one would hardly hear the term 'righteousness' or even being declared 'just'. In a post-modern society it boils down to 'matters of fact' and 'matters of law' by which court(s) of law will judge 'guilty' or 'not guilty'.

12 (Holst, 1997:319-320). Moo (1996:86) comments that for Paul God is the one who justifies and the human being is always the one being justified.

13 It is thus inevitable that Paul would have demonstrated sin as universal in character. For Paul those who are wicked suppress the truth (Rom 1:18); they (humanity as a whole) claimed to be wise, but became fools by exchanging the immortal God with images resembling mortal human beings (Rom 1:23). They exchanged the truth for a lie and worshipped the creature rather than the Creator (Rom 1:25); alluding to Genesis 2:4a$3: 25$. Apart from describing the action of such foolish, wicked individuals in Romans $1: 29-31$, it is clear that for Paul wickedness or ungodliness is the conduct of someone who exchanges the truth for a lie, who exchanges the immortal God with mortal beings. 
Faith communities have no say in this matter. In fact, during the Oscar Pistorius trail which lasted nine months, no theologian, reverend or any other representative of faith communities were consulted - even though they are the ones proclaiming the concept 'righteousness through faith' or 'justified by faith'. That being said, a working definition of being 'just' and 'righteous' is a state of 'being made possible by the act of judgment' or 'declaration of righteousness' should suffice. In Paul's mind being declared 'just' or 'righteous' is a divine act based on faith of a mortal as is imminent from Genesis 15:1-21 from where he quotes and which informs his hermeneutical processes in this regard. ${ }^{14}$

\section{A brief analysis of Genesis $15: 1-21^{15}$}

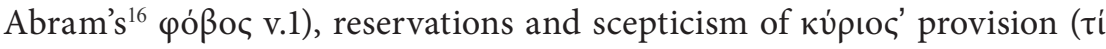
$\mu$ o $\delta \omega \sigma \varepsilon เ \varsigma)$ in Genesis 15:2 is, in the first instance, based on the fact that he is without children. ${ }^{17}$ Abram's cynical attitude is further emphasised in Genesis 15:4-5, relating to the promises made by kúpıьc. ${ }^{18}$ Abram's doubt is introduced after the first words spoken by kúpıৎ in Genesis 15:1b

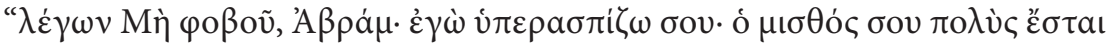
$\sigma \varphi o ́ \delta \rho a "{ }^{19}$ The response in v.1b is that Abram is not to fear, кúpıoৎ himself will be his shield bearer, the one who will reward in extreme abundance. The challenge though is that Abram's reality simply does not reflect what kúpıoc is uttering. In fact, Abram counters the words spoken by кúpı๐ stating that

14 According to Moo (1996:86) Roman Catholic scholars insist that being declared righteous include moral transformation.

15 Oeming's (1998:16) opening words in his essay contribution to Heinz-Josef Fabry's festschrift, is that one can rightfully describe Genesis 15 as the summary and theological kernel of the Abraham material. Gaston (1980:41), requests that Genesis 15:6 should be read in the context of Genesis 15 and not in the light of a Christian concept of justification by faith.

16 The shortened translated 'Abram' will be used when dealing with Genesis 15:1-21 (as it appears in the Greek Old Testament text), but the longer form 'Abraham' will be used when considering Romans 4.

17 (Oeming, 1998:17).

18 When terms such as кúpıoৎ and $\theta \varepsilon$ ć ৎ are used to refer to the Hebrew deity, I will not be using the translated terms 'Lord' and 'God' respectively. The reason for this is that I consider the nuanced use important for theological and conceptual reasons.

19 For Oeming (1998:17) the 'words spoken by YHWH sounds like an abstract kerygma theology. 


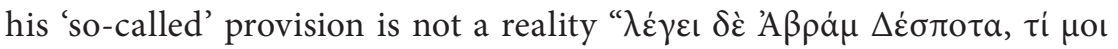

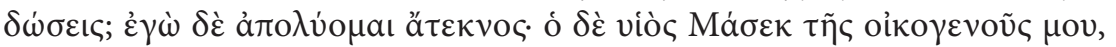

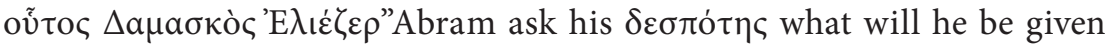
because he is childless, andthe son Masek of his homebred is Damascus Elizier. ${ }^{20}$ After Abram's response, it is $\theta \varepsilon$ co

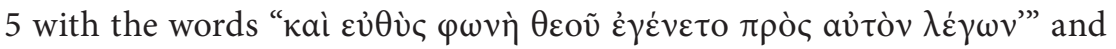
immediately a voice of God towards him saying. The reply is not so much directed at how Abram perceives his own reality but a clarification, and with that, an elaboration of what is to be expected is offered in turn:

- One of Abram's own will be his heir (v. 4b).

- God took Abram outside, made him look up at the stars in heaven, while a promise was made that his descendants will be as many as the stars he can count (v. 5a-c).

Astoundingly, after these 'extravagant' and somewhat unrealistic promises

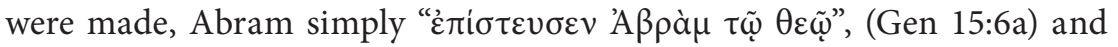

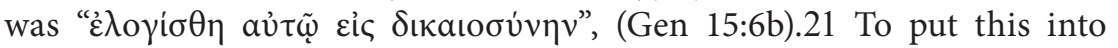
perspective; the lord appears to Abram in a vision declaring that Abram should not be afraid because he (the lord) is the shield and that Abram will be rewarded. Abram responded sceptically at first due to an honest reflection on his reality, followed by an almost unrealistic promise that resulted in Abram accepting it as 'fact' and by doing so he is declared 'righteous. ${ }^{22}$ Noteworthy is that Abram is the active agent; it is due to the act of 'believing' that he is considered 'righteous. ${ }^{23}$ One cannot ignore the fact that the phrases in Genesis 15:6 does not fit in well with what proceeds or

20 As a nomad, a life that is not passed on from Father to son, is no life at all, it is not a holy or blessed life (Westermann, 1981:261).

21 The Hebrew used Hif'il form of the verb ומא (believe, trust) and הקדצ (righteous), and

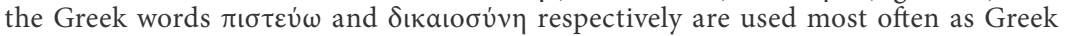
counterparts for these terms.

22 Westermann (1981:255-256) asserts that Genesis 15 is a compilation of two separate promise narratives that was weaved together (von Rad, 1972:182). This would explain why Genesis 15:6 end the way it does and for Abram's scepticism to be 'repeated'. The fact remains that both these narratives testify to Abram's scepticism. The contradictions found in Genesis 15 (von Rad, 1972:182) suggest that this chapter cannot be approached as an organic narrative unit. Oeming (1998:18) comes to the conclusion that 'faith' or the act of 'believing' is in essence existential trust in the future.

23 See the discussion regarding Abram as active of passive agent in Oeming (1998:19-22); (Köckert, 2012:415-418). 
follows it. This is emphasised by the fact that in Genesis 15:7 $\theta \varepsilon$ ó Abram that he was the one that took him from Ur of the Chaldeans and

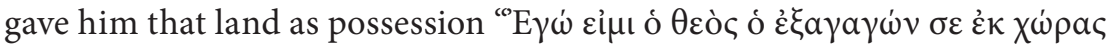

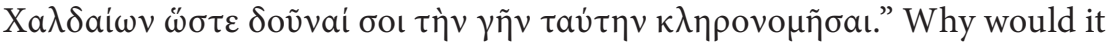
have been necessary for further argumentation and substantiation if Abram believed and was declared righteous in Genesis 15:6? The opinion here is

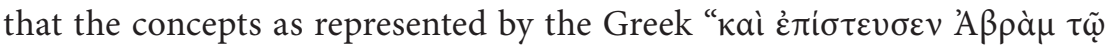

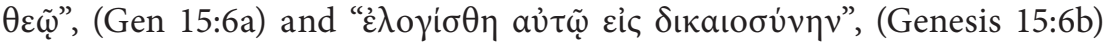
was added, prematurely so, by a redactor of the Masoretic text and merely translated into Greek. If one would 'ignore' Genesis 15:6 for a moment, then Abram's response in Genesis 15:8 is not surprising. He remains doubtful, almost cynical, inferred from the question he asks: how can he be sure that the land will be his and his heirs? After failure to convince Abram, kúpıoc commanded Abram to make an offer (Gen 15:10-11) after which Abram fell asleep and it was then that a thick dreadful darkness came over him

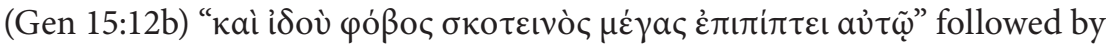
the lord's punishment, presumably due to the 'lack' of Abram's faith. The supposed 'punishment' is followed by affirmation that on that day the lord made a covenant with Abram that they (his descendants) will be given the land as promised (Gen 15:17-21). The outcome of this divine oracle between 'Abram the sceptic' and 'God the profligate promiser' is to a certain degree disappointing because it is not dominated by a honest reflection on what is real, but dictated by lavish promises accompanied by certain conditions, circumstances and clarifications. ${ }^{24}$ The 'sceptical', 'faithful' and 'righteously declared' Abram disappears from the scene after he fell into a deep sleep. One would have wanted Abram and $\theta \varepsilon$ ó s to continue conversing with each other as to get to a sounder understanding of what is real and how Abram is to deal with his reality in relation to the Hebrew deity. Abram's submissive and humble response is emphasized with the use of the term $\delta \varepsilon \sigma \pi$ ó $\tau \varsigma,{ }^{25}$ while its Hebrew counterpart reads הוהי ינדא, the translation of which is problematic but the concept intended with the use

24 This reminds one of the response in Mal. 3:1-5 after a relevant and critical question is

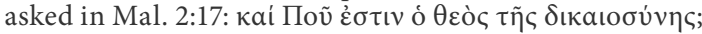

25 The use of the term $\delta \dot{\varepsilon} \sigma \pi$ tr $\rceil \varsigma$ in the Septuagint (the term 'Septuagint' is used in its broadest and critical sense. It is a term that represents the Greek Old Testament as reconstructed in the Göttingen critical edition). In the case of Genesis, Wevers (ed., 1974) was consulted. 
of the two terms in combination is reproduced in the English language with Lord God. This is a clear sign of a theologically loaded conceptual shift between the Hebrew and Greek versions of the Old Testament. But this is not the only reason why Genesis 15:6 became something that was not, it seems, intended. Based on this preliminary analysis of Genesis 15:1-21, it seems to be reasonable to conclude that:

1. Being declared righteous does allow for sceptical faith to a certain extent. $^{26}$

2. The theology of the author dominates the oracle and by this; the oracle is therefore not a true reflection of the Hebrew deity's engagement with Abram, but a tool to justify the theological perspective of the author.

3. The cynical nature of faith has negative consequences and thus almost 'forces' the author to portray the Hebrew deity in a lavish and extravagant way. ${ }^{27}$

4. The act of faith and declaration of being righteous does not dominate Genesis 15:1-21.

It is therefore reasonable to infer that it is not righteousness through faith that takes centre stage, but the sceptical and cynical nature of Abram as the 'father' of the one who ultimately comes to faith. The Hebrew deity did not declare Abram righteous based on the action of faith or trust. It was his scepticism and cynical nature that forced 'promises', 'elaborations', 'conditions' and 'compromises.' Hence, to be declared 'righteous' by the Hebrew deity, in this case at least, is not an act of such deity, but a process; so too is faith. The tone of the oracle in Genesis 15:1-21 reminds one of Job and his critical stance towards the Hebrew deity due to his circumstances. What is of great interest and significance is how Paul interpreted and understood Genesis 15:1-21; and to what extent Genesis 15:1-21 influenced his concept of righteousness through faith.

26 This deduction is true for both the Masoretic and Greek text versions.

27 The Job narrative is a perfect case in point. Job asks reasonable and relevant questions and the author allows for this to a certain extent, but Job's response is soon countered by the Hebrew deity's response in Ch. 39 onwards. 


\section{Paul's interpretation of Genesis 15:1-21}

By introducing 'A paà $\mu$ in Romans 4 Paul would have called an array of 'ideas', 'concepts', 'emotions', and 'practices' to mind; even a sense of 'heritage', 'identity' and 'legacy'.28 The question posed in Romans 4:1

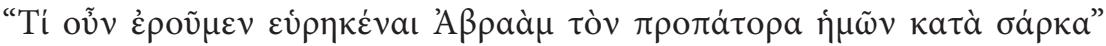

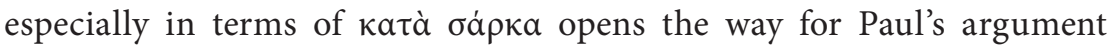

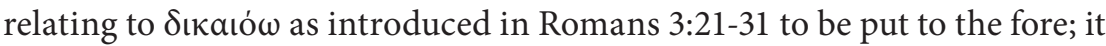
also sets the stage for the Genesis 15:6 citation. Paul argues that Abraham's boasting cannot be warranted if he was declared righteous through his works. It is not immediately clear whether the conditional clause " $\alpha \lambda \lambda$ ' ov

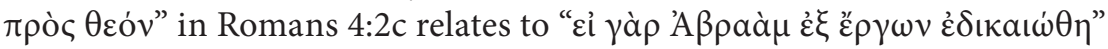

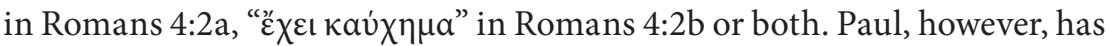
already conceptually intertwined the concept of 'boasting' and 'declared

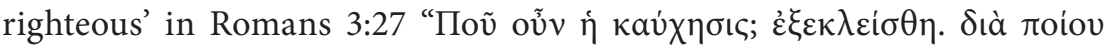

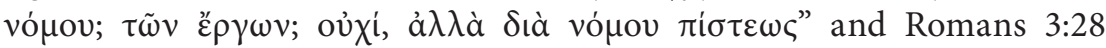

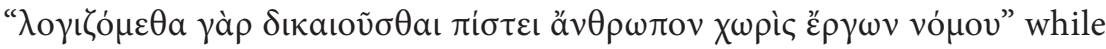
introducing the concept of faith. It is thus reasonable to infer from Romans 3:27 and Romans 3:28 that neither 'boasting' nor 'being righteous' through works has any relevance before $\theta \varepsilon$ ó $\varsigma$. Paul presupposes that faith, rooted in grace, is the only way one can be considered 'righteous' and declared 'just'. ${ }^{29}$ The possible reason for such a presumption was brought about by a desperation to 'justify' his mission to the 'non-Jews'. ${ }^{30}$ But for Paul to have argued from such a premise he had to prove that righteousness through faith applies to both Jews and 'non-Jews'. ${ }^{31}$ It is within this context that Paul quoted Genesis 15:6. ${ }^{32}$

28 It cannot be denied that Abraham was a significant cultural, religious and identity forming figure during the exilic and post-exilic period.

29 Hahn (2011:253-254) draws a valuable distinction between the different ways of

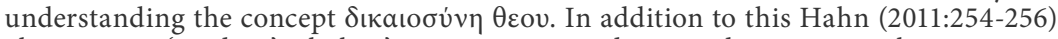
also presents 'modern' scholars' interpretation and assigned meaning to the concept.

30 (cf. Dunn, 2003:425).

31 (cf. Hahn, 2011:257).

32 Nickelsburg (2005:70) highlights that the sacrifice of Isaac and the purchase of the Cave of Machpelah is expanded to depict Abraham as a paragon of faithfulness and patient endurance which is celebrated in Genesis 15:6, among others. It seems to be obvious that Paul too wanted to celebrate Abraham's faith when he quoted Genesis 15:6. Also see Koch's presentation of the Textgrundlage of the Pauline citations (1986:48-88) and Stanley (1992:100) in the case of Romans 4:3. 
If there was any confusion regarding the authority of the cited text, such confusion would have been cleared with the introductory formula " $\tau \dot{i} \gamma$ $\alpha \rho$

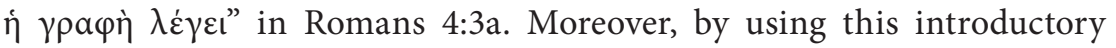
formula, Paul kept with the dialogue tone and structure of Genesis 15, dominated by words 'spoken' by the Hebrew deity and Abram responding

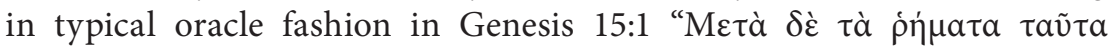

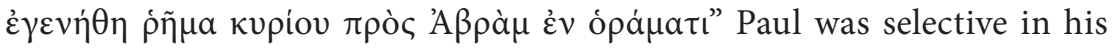
use of Genesis 15:6, even though he might have had a manuscript to his disposal and read the text within its macro-context. Paul was not in the least interested in a typical 'modern'-'western' historical-critical analysis of the text in combination with socio-rhetorical critical considerations. ${ }^{33}$ There was no desire to get to the original meaning or to extract facts from his manuscript. All Paul had to do was to point to a legendary figure, make it explicit that what is to follow it is taken for the 'holy' scriptures to get the attention of his audience. His intent was not to reconstruct an 'authentic' past, neither to seek the 'truth'. Paul wanted to argue that 'righteousness' and 'justice' is accessible for both Jew and 'non-Jew' because one is declared righteous through faith. He uses Abram as the nomadic father of the Jews

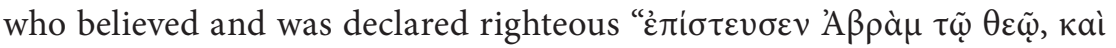

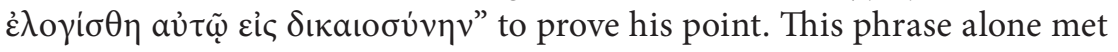
all the requirements that would support his argument. There would have been little or no dispute that Abraham was indeed a legendary figure within the Jewish faith, the founding father of Israel as a people. By showing that Abraham was declared righteous purely because he 'believed', ensured that the criteria of faith was a legitimate criterion for the Jews, and therefore such a criterion would be equally appropriate for 'non-Jews'. It appears as if Paul is not in the least interested in Abraham's cynical attitude or his scepticism.

Paul continues with his exegesis of Genesis 15:1-21 stating that the promise made to Abraham did not come via the law, but by 'righteousness through

33 Von Achim (1997:327), comments that a historical understanding of the Old Testament texts is an obstacle for a Church-dogmatic interpretation, which has a negative impact on Christian theology as a whole. This would be true for Paul's interpretation of Genesis 15:1-21 as well. Paul's exegesis would be in line with a 'church-dogmatic' interpretation of the Old Testament text. His aim is to concretely determine the Wirkungsgeschichte of Genesis 15:6 as understood by Paul (Von Achim, 1997:328). 


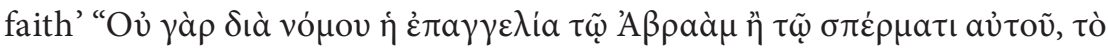

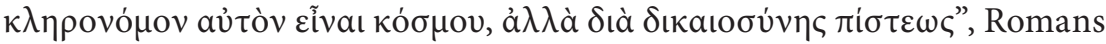
4:13. Paul argues that if those that inherit does so based on the law, the promise is void and faith nullified (Rom 4:14). With such a notion Paul implicitly reveals his logic and of course theological frame of reference. A promise made by a Hebrew deity and faith in such a promise supersedes Jewish law on inheritance. ${ }^{34}$ Paul is inclined to argue this, because he had to incorporate the 'non-Jews'; not on legal grounds but based on faith in the one that is the ultimately the supreme Judge. Ironically, it is not so much Abraham's faith, but his scepticism that kept on 'demanding' more from the one that will eventually declare him righteous. Therefore, it seems premature to declare Abraham righteous in Genesis 15:6 because he was sceptical at first (Gen 15:2-3), but after he was shown the stars, Abram believe the lord and he was declared righteous, just to be sceptical yet again on the promise of inheriting land (Gen 15:8). Paul's interpretation of Genesis 15:1-21 does not allow for Abraham's scepticism or cynical nature. It is either due to the fact that he was oblivious to the author's aim or he simply ignored it and focused on what he considered important, being the content in Genesis 15:6; that one is declared 'righteous through faith'. For the redactor of Genesis 15:1-21 though, addressing the issue of exile, while alluding to the enslavement in Egypt and framing that within the concept of the covenant seems to have been his primary aim. ${ }^{35}$ Abraham as a nomadic, non-institutionalised figure was used to explain the negative situation the Israel elite found themselves in and to give hope to those who were taken into exile. The author theologically interpreted his sociocultural context, a historical situation of people in despair. The latter is emphasised by the prominence of the Lord's promise not as a result of faith, but of scepticism, that would have reflected the attitude of those currently in exile. His theological response involved none other than Abram, hence opening the possibility for Paul to reinterpret Genesis 15:1-21 for his own purpose. But the scepticism and historical situation was not something

34 Holst (1997:319), is of the opinion that Paul's choice of Genesis 15:6 shows persuasion of the promises as they are summed up in Christ, 319. He further states that Abram believed in God's promises and not believed in God; and to argue to opposite will be to introduce a false and misleading dichotomy.

35 See Oeming (1998:16-17) and the possibilities he proposed in this regard. 
Paul wanted to play into because it simply did not serve his theological aim of including 'non-Jews' by means of faith. ${ }^{36}$ Paul's logic ${ }^{37}$ unfolds as follows:

1. The law results in punishment, but if there is no law, there is no transgression (v. 15).

2. Faith through grace ensured sustainability of the promise for the heirs (v. 16a).

3. Heirs, not due to the law alone, but also because of Abraham's faith, who is the father of everyone (v. 16b).

4. Abraham is made the father of many nations before God, whom he believed in (v. 17a).

5. He (God) who gives life to the dead and who calls things into existence that does not exist (v. 17b).

6. He (Abraham) believed he would become the father of many nations according to what was said (v. 18).

7. Abraham did not weaken his faith based on the reality that he was 100 years old and that his wife, Sarah had not yet bared a child (v. 19).

8. No distrust made Abraham waver the promise made by God, his faith grew stronger (v. 20).

9. Abraham was convinced that God would be able to do what he promised (v. 21).

10. Abraham was considered 'righteous' (v. 22).

It is clear from this interpretation of Genesis 15:1-21 that Paul is not in the least interested in Abraham's scepticism. It does, however, seems as if he is countering such a notion. For this reason, Romans 4:18-21 deserves closer investigation. According to Paul, Abraham hoped against all hope, believed he will become father of many nations based on what was said

36 Holst (1997:320) will argue that Romans 4 makes clear that God's self-disclosure through the word of promise is the reason for Abraham's subjective faith, and that apart from it an analysis of this faith is impossible.

37 The implied logic regarding the promise and believe in such a promise is that without the divine word, Abraham could not have been justified because he could not have become a believer (Holst, 1997:320). 


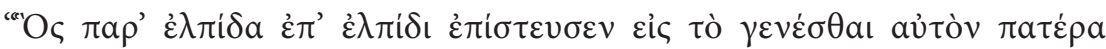

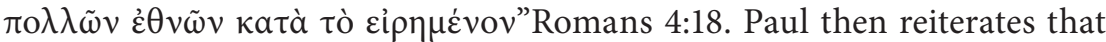

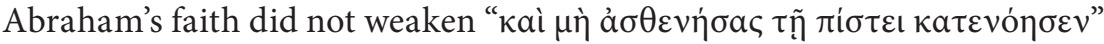
even when he was as good as dead because he was over a hundred years old and considering the barrenness of Sarah's womb (Rom 4:19). The situation painted by Genesis 15:1-21 and further, suggests that Abraham's faith did indeed weaken. This is not only clear from his persistent scepticism, but also inferred from his decision to have intercourse with his wife's slave, Hagar, so to build a family (Gen 16:1-4a). Paul seems convinced that Abraham did not at any point doubt God's promise when he says that there was no

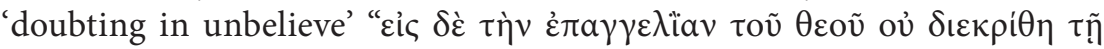

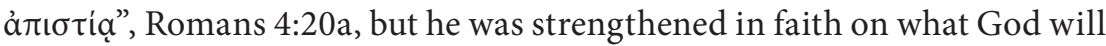

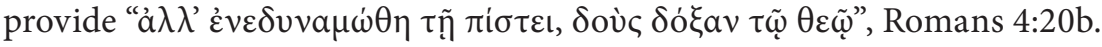

These statements made by Paul is not a true reflection of Genesis 15:1-21, but it confirms Paul's presupposition and aim. His arguments on 'justice' and 'righteousness' is not informed by facts or what is indeed 'real' in terms of the outcome of the promises made. Abraham's faith and subsequent glory to God (Gen 15:20) is debatable and the inheritance of the 'promised land' is highly questionable. The concept of faith was the 'saving grace' for Paul's argument on 'righteousness' and 'justice'. The action of 'believing' is the key ingredient to be declared righteous by God. Abraham believed in God's promise, while the gentiles and others believed in Jesus. The same entity will declare them righteous through the act of 'believing'. Jesus was also raised from the dead for the believers' justification (Rom 4:25). For Paul's argument to work, it was crucial for him not to focus on the facts of the content matter, neither should he have considered the facts of the matter referred to within the content matter. To rephrase this, Paul had to ignore Abraham's persistent scepticism and the fact that the promise never came to fulfilment; certainly not at the time Paul wrote this letter. Abraham and his descendants (presumably referring to Israel) did not inherit any land up until this very day, nor were his descendants (if interpreted as the ones believing) as many as the stars. Paul as a prominent and well educated diaspora Jew, who prosecuted the followers of Jesus, just to become a follower himself, was forced by his own personal circumstances and sociohistorical context to make the new dimension of the Jewish faith inclusive as appose to being exclusive. The only way possible was to indicate that one 
can only be declared righteous through faith. Romans 4:6-12 emphasises Paul's aim and approach.

\section{Excursion: Romans 4:6-12}

The fact that Paul is not in the least interested in constructing a historical critical background in support of his argument, is confirmed by the introductory formula and the explicit citations taken from Psalm 32:1 (Rom 4:7) and Psalm 32:2 (Rom 4:8). These citations once again reveal that he is counting on Jewish tradition and sentiment to further his

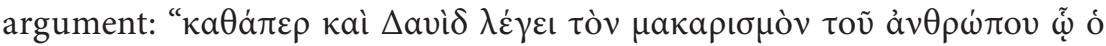

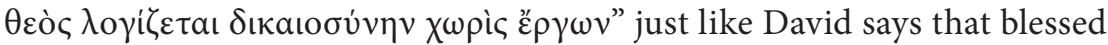
are those declared 'righteous' by God apart from 'works'. Not only was Abraham declared righteous because of his faith, but even king David said people who are declared 'righteous apart from works' are blessed. And if anyone doubted that David said this, Paul countered all doubt with an explicit citation resembling Psalm 32:1, 2. The issue of circumcision in relation to righteousness through faith is introduced here. The logic of Paul's argument is that if Abraham was considered 'righteous through faith' and if he received circumcision after being deemed 'righteous', then the obvious conclusion is that circumcision is not a prerequisite to be reckoned 'righteous'. According to Paul, Abraham is the ancestor of the JewishGentile believers, which makes him the ancestor of both the circumcised and the uncircumcised. Again, Paul's primary motif is highlighted, that he had to justify his mission to the 'non-Jews'. It was not that Paul was necessarily ignorant of, or that he blatantly ignored the literary context of both Genesis 15 and Psalm 32. He knew that both Abraham and David will call up a sense of 'heritage', 'tradition', 'legacy', 'sentiment' and 'nostalgia'. Abraham was declared 'righteous through faith' and David considered those, whose sin the Lord will not reckon, as blessed. Paul's exegetical tactics had all the credentials to convince the Jews that 'non-Jews' were also heirs of God's kingdom and declared righteous due to their faith. Paul understood the divine oracle (Gen 15:1-21) and the poem of guilt and forgiveness (Psalm 32) as proof texts that anyone who believes has access to God's forgiveness and grace.

What is ironic, though, is the that if Paul paid more attention to Abram's scepticism and cynicism in Genesis 15:1-21 he would not have been as 
effective with his first-century audience, but he would have been highly relevant and valued in a 'postmodern' age and would therefore have contributed to the liberation of the stagnate position of 'justification by faith'. It would thus be fair to assert at this juncture that for Paul 'fact' or 'truth', in the historical-critical sense of the word, has little or no relevance for 'righteousness' or the 'act of believing'.

\section{Conclusion}

The concept of 'righteousness through faith', culminating into justification through the same faith has shaped both Protestant and Catholic theology alike. The dogma 'righteousness through faith' or 'justification by faith', as developed by Paul, is generally accepted by most (if not all) Christian traditions. This, in addition to the uncritical and indiscriminate attitude towards the concept, has caused the concept to morph into a terminus technicus resulting in the theological demise of the concept and its relevance and value highly questionable. It would, however, be futile to deny, discard or even reject such a concept. The aim with this study was to contribute to the liberation of the concept from its theological stagnate position through a critical investigation into Paul's quotation of Genesis 15:6 in Romans 4:3 as part of his reinterpretation of Genesis 15:1-21.

The first obvious conclusion is that the concept 'righteousness through faith' or 'justification by faith' has little or no relevance for the current postmodern secular society. One could even go as far as to say that the concept holds no immediate tangible relevance for faith communities. Faith communities have for far too long unconditionally accepted Paul's concept of 'righteousness through faith'. This caused, to the opinion held here, the concept to become stagnate and its relevance and value uncertain. The brief analysis of Genesis 15:1-21 has shown that Abram's scepticism and cynicism formed an integral part of the process to declare Abram 'righteous'. Faith, it seems, does not play a major part in the 'righteous' declaring process, but it is a final act by the subject who is to be declared 'righteous'. ${ }^{38}$ Moreover, the act of faith also prepares the subject for a

38 It was not initially a 'final' act, but the insertion of Genesis 15:6 forces one to understand it as such. 
repetitive process of scepticism, cynicism and again faith. Paul, in turn, does not allow for any scepticism and cynicism in his interpretation of Genesis 15:1-21. Paul did not have much of a choice; he had to be selective in his approach to Genesis 15:1-21. The only way he knew to convince his fellow Jews that 'non-Jews' can also be declared 'righteous' and be accepted by the Hebrew deity and by so doing form part of the 'chosen' people, was to focus on the act of faith of being declared 'righteous'. Paul gives the impression that scepticism and cynicism does not possess the necessary 'inclusive' and 'universal' characteristics as the idea of faith does. Abram, the father of Israel as a society, believed in the Hebrew deity and the 'non-Jews' believed in Jesus. The logic inference is that the act of faith will redeem both Jew and 'non-Jew' through which they will be declared 'righteous'. One has sympathy for the fact that Paul wanted to be 'inclusive' in his approach, while justifying his mission to the 'non-Jews'. Paul's aim was simply to make God's promise of inheritance accessible to the 'non-Jews'. A cause that is 'just', 'worthy' and 'morally commendable'. The reality is that it was in fact Abram's scepticism and cynicism that eventually 'forced' an act of faith; hence a declaration of righteousness. Ironically, if Paul's context allowed him to make more of Abram's scepticism and cynicism he would not have been as affective to communicate and justify the Hebrew deity's plan of redemption that includes both Jew and 'non-Jew'; but the concept would then have possessed enough crucial and identifiable elements to have made it universally more relevant for a postmodern secular society. On the question if the concept of 'righteousness through faith' as developed by Paul in Romans 4 is universally 'true', 'relevant', 'valuable' and 'justifiable', the answer has to be no.

\section{Bibliography}

Brown, F, Driver, SR \& Briggs, CA 1977. Enhanced Brown-Driver-Briggs Hebrew and English Lexicon. Oxford: Claredon Press.

Dunn. JDG 1998. The Theology of Paul the Apostle. Edinburgh: T \& T Clark.

Gaston, L 1980. Abraham and the righteousness of God. Horizons in Biblical Theology 2:39-68. 
Gesenius, W \& Tregelles, SP 2003. Gesenius' Hebrew and Chaldee Lexicon to the Old Testament Scriptures. Bellingham, WA: Logos Bible Software.

Hahn. F 2011. Theologie des Neuen Testaments Bd. 1: Die Vielfalt des Neuen Testaments. UTB Series. Tübingen: Möhr \& Siebeck.

Holladay, WL \& Köhler, L 2000. A Concise Hebrew and Aramaic Lexicon of the Old Testament. Leiden: Brill.

Holst, R 1997. The meaning of "Abraham believed God" in Romans 4:3. Westminster Theological Journal 59, 2:319-326.

Käsemann, E 1980. Commentary on Romans. G.W. Bromiley (tr., ed.). Grand Rapids, Michigan: Wm. B. Eerdmans Publishing Co.

Koch, DA 1986. Die Schrift als Zeuge des Evangeliums: Untersuchungen zur Verwendung und zum Verständnis der Schrift bei Paulus. Tübingen: Mohr Siebeck.

Köckert, M 2012. Glaube und Gerechtichkeit in Genesis 15,6. Zeitschrift für Theologie und Kirche, 109:415-444.

Krašovec, J 2014. Justification of God in His Word in Ps 51:6 and Rom 3:4. Vetus Testamentum 64, 3:416-433.

Liddell, HG 1996. A Lexicon: Abridged from Liddell and Scott's GreekEnglish Lexicon. Oak Harbor, WA: Logos Research Systems, Inc.

Lohse, E 2003. Der Brief and die Romer. Kritisch-Exegetischer Kommentar über das Neue Testament. Göttingen: Vanderhoeck \& Ruprecht.

Louw, JP \& Nida, EA 1996. Greek-English Lexicon of the New Testament: Based on Semantic Domains. New York: United Bible Societies.

Lust, J, Eynikel, E \& Hauspie, K 2003. A Greek-English Lexicon of the

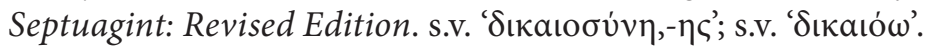
Stuttgart: Deutsche Bibelgesellschaft.

Moo, DJ 1996. The Epistle to the Romans. New International Commentary on the New Testament. Grand Rapids, Michigan: W.B. Eerdmans.

Muraoka, T 2009. A Greek-English Lexicon of the Septuagint. Louvain/ Paris/Walpole, MA: Peeters. 
Nickelsburg, GWE 2005. Jewish Literature between the Bible and the Mishnah. Second Edition. Minneapolis: Fortress Press.

Oeming, M 1983. Ist Genesis 15,6 ein Beleg für die Anrechnung des Glauvens zur Gerechtigkeit? Zeitschrift für die alttestamentliche Wissenschaft, 95:182-197

- 1998. Der Glaube Abrahams zür Rezeptionsgeschichte von Genesis 15,6 in der Zeit des zweiten Tempels. Zeitschrift für die altestamentliche Wissenschaft, 110:16-33.

Schlier, H. 1987. Der Romerbrief. Herders theologischer Kommentar zum Neuen Testament, Band VI. Freiburg, Basel and Wien: Herder.

Schnelle, U. 2003. Paulus. Leben und Denken. de Grutyer Lehrbuch.

Berlin and New York: Walter de Gruyter.

- 2007. Theologie des Neuen Testaments. UTB Series.

Göttingen:Vanderhoeck \& Ruprecht.

Stanley, CD 1992. Paul and the Language of Scripture - Citation Technique in the Pauline Epistles and Contemporary Literature. New York:

Cambridge University Press.

Von Achim, B 1997. Genesis 15,6 und das Vorverständnis des Paulus.

Zeitschrift Für die Alttestamentliche Wissenschaft, 109:327-341.

Von Rad, G 1972. Genesis, A Commentary. Revised Edition. Philadelphia: The Westminster Press.

Westermann, C 1981. Genesis: 2 Teilband. Genesis 12-36. BKAT 1/2. Neukirchen: Neukirchner Verlag.

Wevers, JW (ed.). 1974. Genesis, vol.1: Vetus Testamentum Graecum. Auctoritate Academiae Scientiarum Gottingensis editum. Göttingen: Vanderhoeck \& Ruprecht. 